"When Women Lost the Vote: A Revolutionary Story, 1776 - 1807"

Museum of the American Revolution, Philadelphia PA

Curators: Dr. Philip C. Mead and Dr. Marcela Micucci

Open (as COVID-19 allows) through April 25, 2021; check website prior to visiting

DOI: https://doi.org/10.14713/njs.v7i1.239

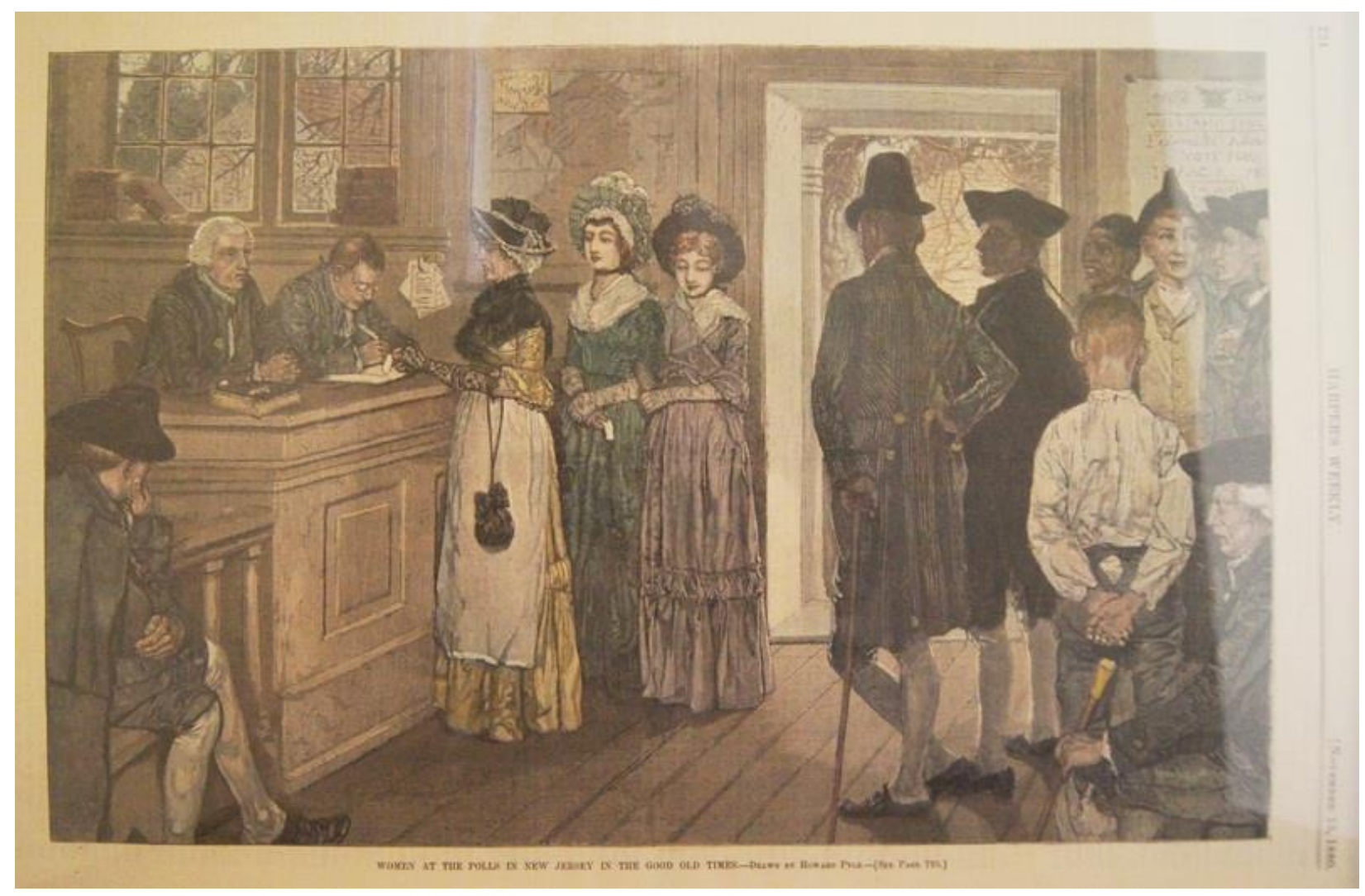

Pyle, Howard, 1853-1911, artist, “Clipping: Harper's Weekly. Women at the polls in New Jersey in the good old times. November 13, 1880," Ann Lewis Women's Suffrage Collection, accessed December 21, 2020, https://lewissuffragecollection.omeka.net/items/show/1371

In their special exhibit, "When Women Lost the Vote," The Museum of the American Revolution explores the little-known history of the nation's first women voters and examines the political conflicts that led to their voting rights being stripped away. Although delayed and intermittently closed by COVID-19, the Museum of the American Revolution's exhibit is to be welcomed for three reasons. First, it brings long-overdue national attention to New Jersey's unique experience of revolutionary female and African American suffrage over a century before the passage of the $19^{\text {th }}$ amendment. Second, in putting together the exhibit, the curators combed 
through voting rolls from the early republic and were able to document actual female voters. Third, it presents that history in a very engaging exhibit along with accompanying material on the web including a New York Times article, WHYY interview, family guide and a virtual exhibit that will be useful for students, teachers, and all who are interested in the foundation of our democracy and ongoing demands for universal suffrage. Highlights for historians include seeing original handwritten letters from Abigail and John Adams, the manuscripts of NJ's 1776 Constitution and 1790 and 1797 statutes with female pronouns, and recently discovered poll books with female names.

The Museum uses an attractive and interactive layout combining historical objects and manuscripts, tableaus, touch screens, films and an audio guide (pdf) to convey a story that is too often overlooked in the way we learn history -- that our history is made up of complex and competing narratives. What did "Liberty" mean? For many colonists, particularly for Native and African Americans, it was not at all obvious whether the British or the Americans offered the better prospects. This is viscerally brought to life by a signed first edition of the poetry collection by enslaved poet Phyllis Wheatley and a talking tableau of the leaders of the Oneida Nations (including two women) arguing over which side to support.

This special exhibit elucidates another fascinating footnote of that overlooked history that some women and African Americans were enfranchised in the early days of New Jersey statehood and then lost that right. Originally planned for a stand-alone gallery, the exhibit was reimagined to be integrated into the main narrative in the museum's galleries after COVID-19.

The first gallery showcases objects representing diverse women of the New Jersey colonies and examines how gender, race, ethnicity, class, and religion all affected women's lives -including how Quaker traditions of gender equality and Dutch traditions of female business 
ownership may have influenced New Jersey's attitude toward women's roles. In what is likely to be a surprise to many visitors (although not the readers of this journal), the exhibit introduces Elizabeth Dorn, a black woman who may have been born enslaved in New Jersey and later became free. The audio guide suggests that she along with other women and people of color could have voted in the state.

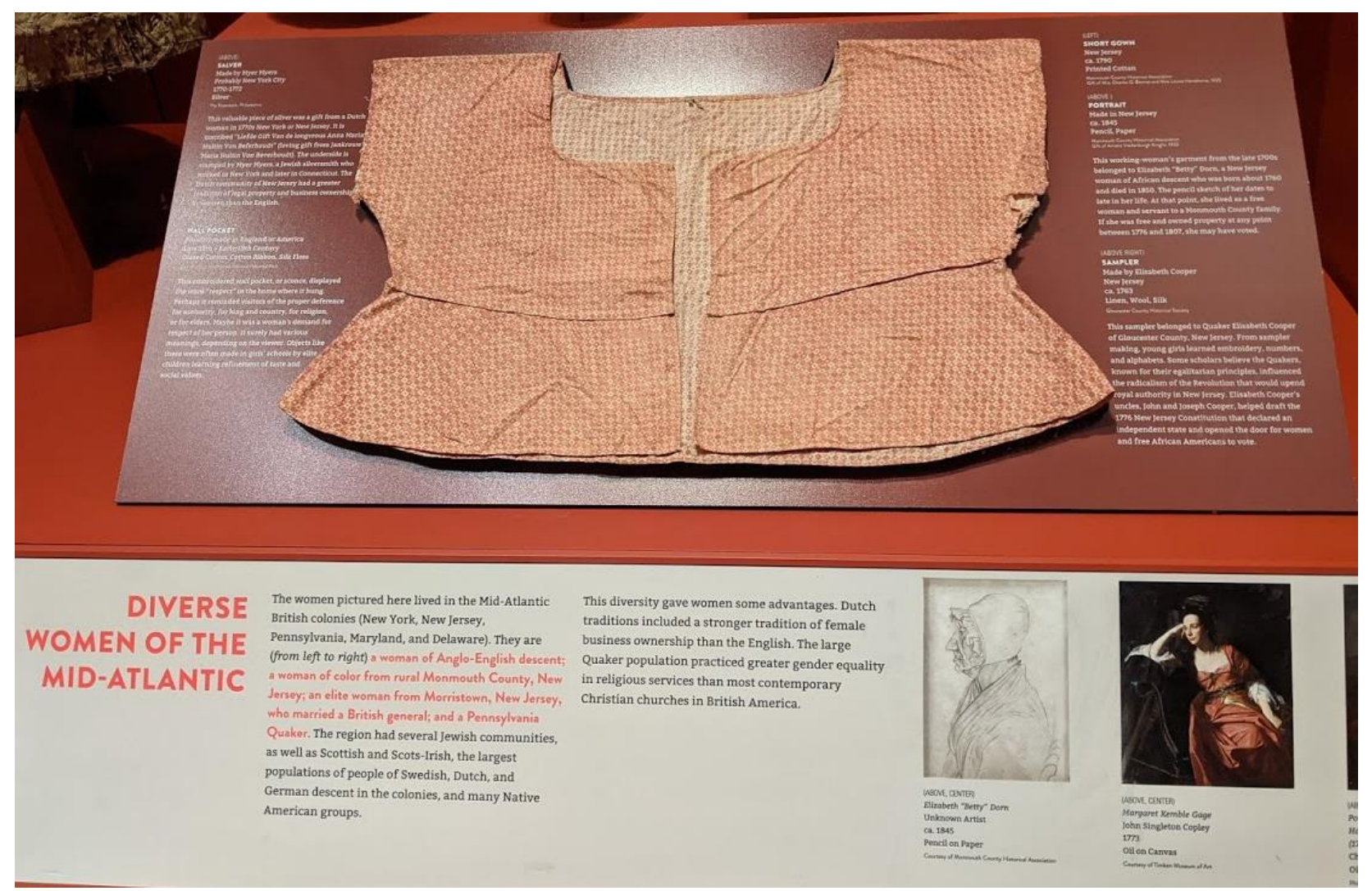

Line drawing portrait and short gown belonging to Elizabeth (Betty) Dorn. (This photo and all following courtesy Carol Simon Levin.)

The exhibit then explores how the colonial rallying cry, "No taxation without representation," exposed a problem in regard to women. Married women were "feme covert" (covered in law by their husbands) so they could not own property. Single women and widows could own property, and thus were taxed, but could not vote.

Rounding the corner, the visitor comes upon one of the delights of the exhibition: Abigail Adams' famous letter to her husband John on March 31, 1776 urging that the Continental Congress 
"remember the ladies" in drafting "the new code of laws" and threatening that if they did not "we are determined to foment a Rebellion, and will not hold ourselves bound by any Laws in which we have no voice, or Representation."

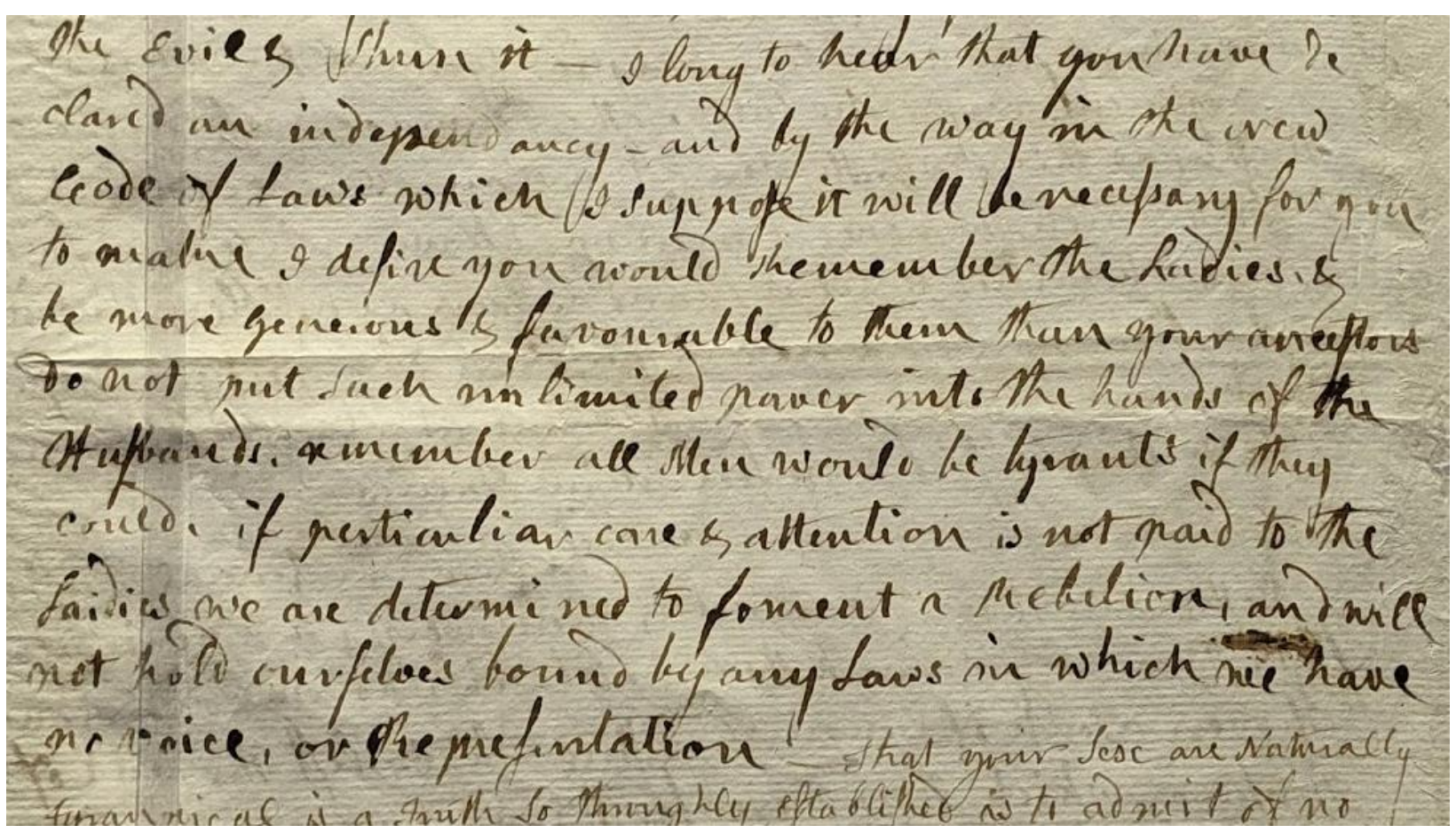

Excerpt of Abigail Adams' March 31, 1776 letter to John "remember the ladies..."

John's mocking reply states she is "so saucy," rails against "the Despotism of the Peticoat," and reflects: "I cannot but laugh -- We have been told that our Struggle has loosened the bands of Government every where. That Children and Apprentices were disobedient -- that Indians slighted their Guardians and Negroes grew insolent to their Masters. But your Letter was the first Intimation that another Tribe more numerous and powerfull than all the rest were grown discontented... We know better than to repeal our Masculine systems." (Both letters are back in Philadelphia for the first time in 244 years.) 


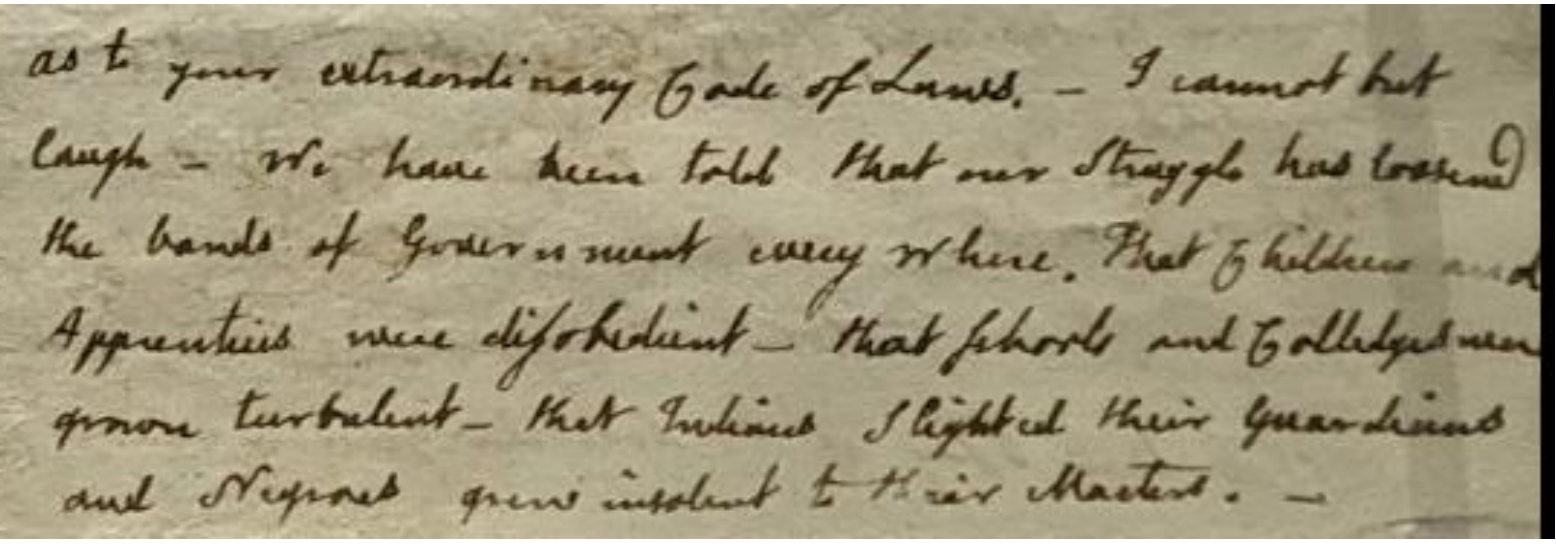

Excerpt of John Adams' April 14, 1776 letter to Abigail "I cannot but laugh..."

We then see Abigail's letter to her friend Mercy Otis Warren asking that she join her in a petition to Congress and her letter to her husband "whilst you are proclaiming peace and good will to Men, Emancipating all Nations, you insist upon retaining and absolute power over Wives."

The final letter in the display is Abigail's 1797 letter to her friend Mary Cranch two decades later musing that if the Massachusetts state constitution were as "liberal" as that of New Jersey and "admitted the females to a Vote" she would certainly have voted on the behalf of her friend's candidate.

All of which are the perfect lead-in to the original manuscripts of New Jersey's July 2, 1776 constitution with its extraordinary gender and race neutral language enfranchising "all inhabitants worth fifty pounds proclamation money..." and use of the pronoun "they" along with the state's 1790 and 1797 laws explicitly adding female pronouns in relation to voting and ballots. Readers will notice that the 1790 handwritten statute has the pronouns in line with the text and in 1797 they were inserted above the text. 


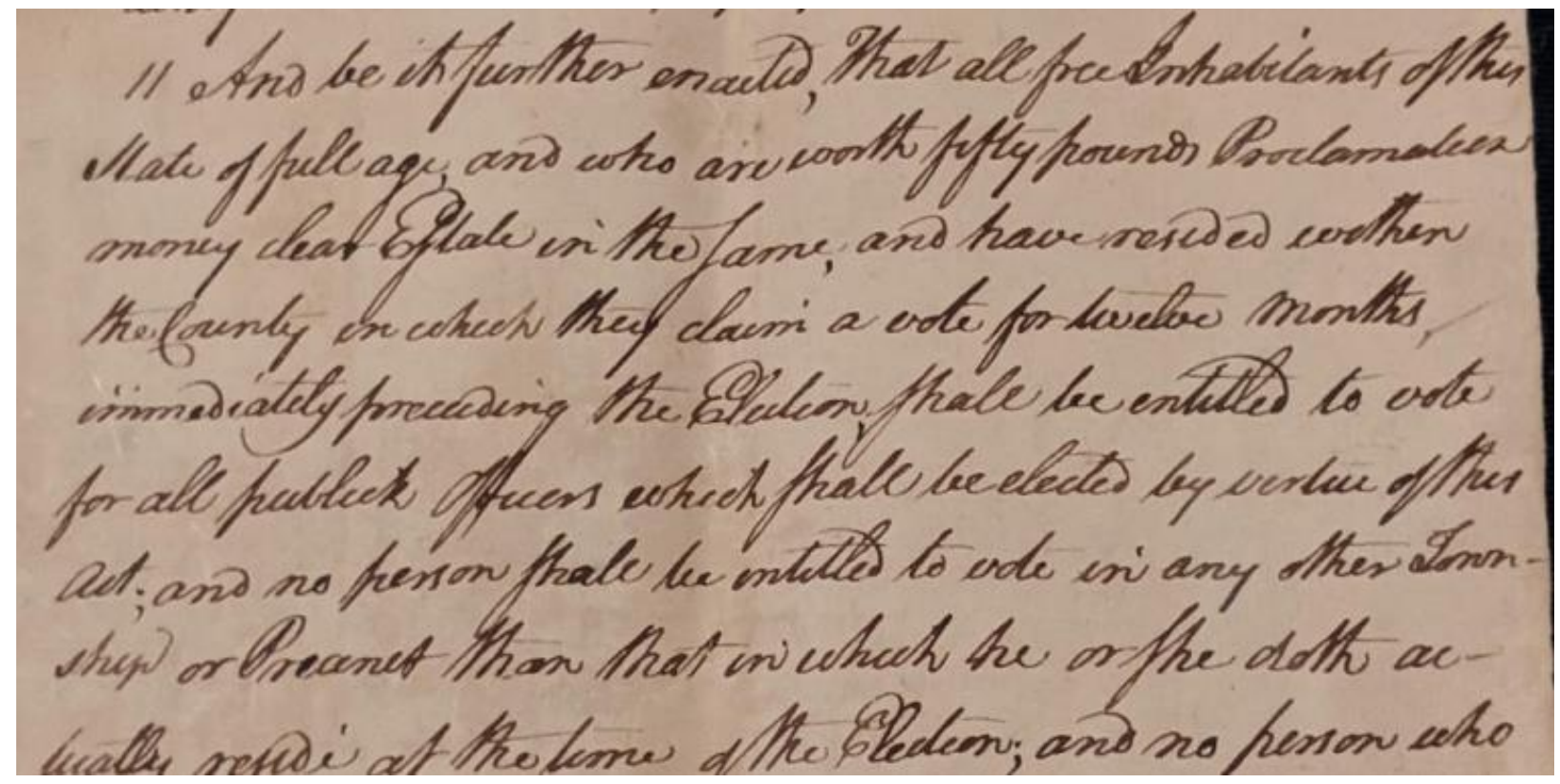

1790: "no person shall be entitled to vote in any other Township or Precinct that that in which he or she doth reside"

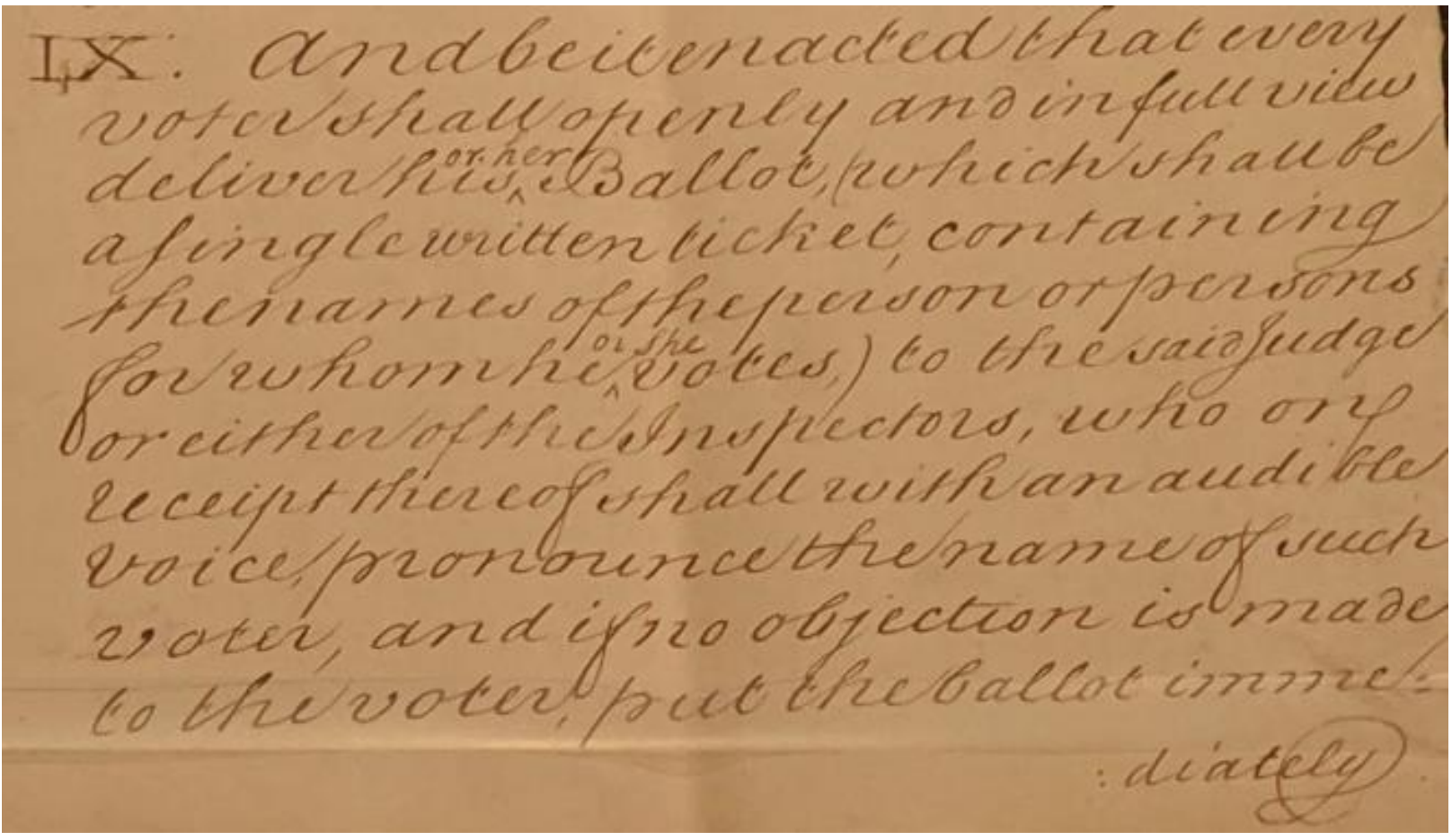

1797: “deliver his or her Ballot” (female pronouns inserted afterwards above text)

After proceeding through rooms featuring revolutionary women at war, a talking tableau exposing the dilemma faced by the six tribes of the Iroquois Confederacy, and a look at the complicated 
calculus of slavery and the revolution, visitors end up in the section featuring the proof that some women in New Jersey actually voted, something previously only known through anecdotal accounts and complaints.

\section{Strength in Numbers?}

Poll lists from early New Jersey show that many women voted in groups. In at least one case, a group of friends from a neighboring church voted together. This might suggest that voting was a social activity. Or, does it indicate that women sought strength in numbers to guard against hostility toward them at the polls? the Montgomery poll list from 1801Grace Little, Hetty Gaw, and Mary Norris also appear listed alongside one another as members of the Princeton Presbyterian Church in January 1807.

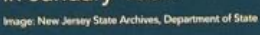

\section{-}




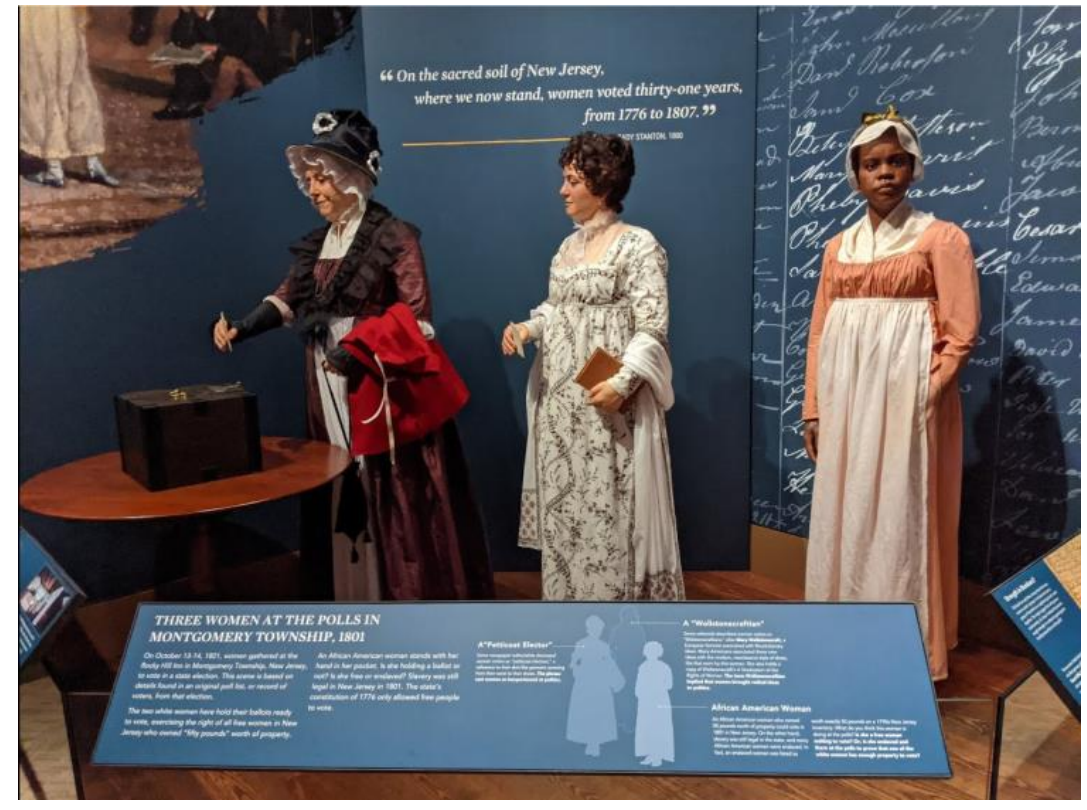

Nearby is a tableau with three women -- two white women hold ballots, the Black woman behind them has her hand in a pocket. It asks the viewer to consider if the black woman is herself a voter or is the enslaved property of one of the others.

Vicious party politics and accusations of voter fraud -- including that married women and enslaved people had voted -ultimately led the all-male NJ legislature to pass a law in 1807 limiting the electorate to "white male citizens worth fifty pounds..." The audio guide to the exhibit ends with this reflection: "In the earliest days of the new United States, women and people of color in New Jersey committed a revolutionary act: they voted. But their story remains a cautionary tale. It suggests that our past has not always been an orderly advancement of progress. Rights and liberties require constant vigilance to preserve and protect. How will you continue the fight?"

As I left the Museum, a helicopter hovered overhead keeping an eye on dueling demonstrations in central Philadelphia as counting continued in the then as yet undecided 2020 presidential election. I couldn't help reflecting on how this was a telling modern reflection of the messy story of our democracy told inside.

Carol Simon Levin is a NJ Council for the Humanities Public Scholar. Information about her programs and links to her publications can be found at tellingherstories.com. 